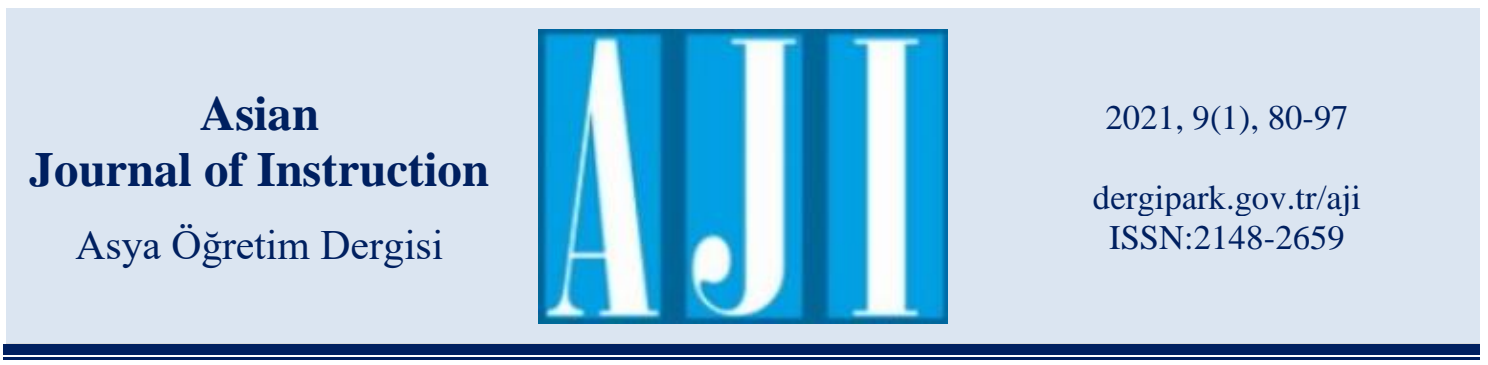

\title{
Öğrencilerin Biyoloji Korkuları ve Biyolojiye Yönelik Tutumları
}

\author{
Murat Özarslan ${ }^{1}$
}

Özarslan, M. (2021). Öğrencilerin biyoloji korkuları ve biyolojiye yönelik tutumları. Asya Öğretim Dergisi, 9(1), 80-97. https://doi.org/10.47215/aji.844015

$\ddot{\mathbf{O z}}$

Çalışmada ortaöğretim kız öğrencilerinin biyoloji korkuları ve sebeplerine ilişkin görüşleri ile biyolojiye yönelik tutumlarının belirlenmesi amaçlanmıştır. Çalışma, 2015-2016 akademik yılı sonunda, Marmara bölgesinin bir ilçe merkezinde Mesleki ve Teknik Anadolu Lisesine devam eden 9. ve 10. sinıftan toplam $70 \mathrm{k} 1 \mathrm{z}$ öğrenci ile gerçekleştirilmiştir. Çalışma grubu, kolay ulaşılabilir durum örneklemesi yöntemi ile belirlenmiştir. Veriler Biyoloji Bilimine ve Dersine Yönelik Tutum Ölçeği ve Biyoloji Korkusu Anketi ile elde edilmiştir. Öğrencilerin biyoloji korkusunun çoğunlukla başarısız olma, konuları anlayamama, öğrendiklerini karıştırma şeklinde olduğu ve bu korkuların sınavlarda soruların çözümünde zorlanma, konuların karışık ve zor olmasından kaynaklandığı tespit edilmiştir. Biyoloji konularında yer alan böcek, virüs, bakteri, bağırsak solucanı, yılan vb. canlıların öğrenciler tarafindan tehlikeli, tiksindirici veya korkutucu olarak algılanması sebebiyle biyoloji korkusu oluştuğu belirlenmiştir. Ayrıca öğrencilerin genetik, insan vücudu gibi zorlandığı biyoloji konularına yönelik korkularının geliştiği bulunmuştur. Öğrencilerin biyoloji ve biyoloji dersine yönelik tutum puanların düşük düzeyde olduğu, bazı öğrencilerin biyoloji dersini sevmedikleri, sıkıcı gördükleri ve ilgilerini çekmediği sonuçlarına ulaşılmıştır. Bu sonuçlar doğrultusunda öğrencilerin biyoloji korkusunun azaltılması ve tutumlarının olumlu yönde geliştirilmesi noktasında eğitimcilere önerilerde bulunulmuştur.

Anahtar Kelimeler: Biyoloji korkusu, tutum, biyoloji eğitimi, çizme-yazma tekniği

\section{Students' Fear of Biology and Their Attitudes towards Biology}

\begin{abstract}
In the study, it is aimed to determine the views of secondary school female students regarding fear of biology and its causes and their attitudes towards biology. The study was conducted at the end of the 2015-2016 academic year with totally 70 female students attending $9^{\text {th }}$ and $10^{\text {th }}$ grade of Vocational and Technical Anatolian High School which is in a district center of the Marmara region. The working group was determined by the easily accessible case sampling method. The data were obtained by Attitude Scale towards Biology Science and Course and by the Questionnaire of Biology Fear. It was determined that the students' fears of biology were mostly in the form of failure, inability to understand subjects, confusing what they had learned, and these fears were resulting from the difficulty in solving questions in exams and the complexity of subjects. As the insects, viruses, bacteria, intestinal worms, snakes, etc. in biology subjects were perceived by students as dangerous, repulsive or frightening, biology became a fear for them. It was also found that students developed fears towards biology subjects which they have difficulty in, such as genetics, human body and systems. It was concluded that students' attitude scores towards biology and biology course were low, some students disliked biology course, found it boring and had no interest for it. In line with these results,
\end{abstract}

${ }^{1}$ Dr, MEB, , https://orcid.org/0000-0003-2139-4347, muratozarslan14@gmail.com 
Öğrencilerin Biyoloji Korkusu ve Biyolojiye Yönelik Tutumları

suggestions were made to educators to reduce the fear of biology and to improve the attitudes of the students in a positive way.

Keywords: Fear of biology, attitude, biology education, drawing-writing technique

\section{Giriş}

Türkiye'nin Uluslararası Öğrenci Değerlendirme Sınavı'nda (PISA) fen bilimleri ve matematik başarısının son yıllarda dünya ortalamasından düşük olduğu değerlendirilmektedir (Berberoğlu, 2007; MEB, 2015; Taş, Arıcı, Ozarkan \& Özgürlük, 2016). Benzer şekilde ulusal veya yerelde yapılan sınavlarda da öğrencilerin fen ve matematik alanlarında istenilen başarıyı sağlayamadığı belirlenmiştir (Uyanık, Güler, Teker \& Demir, 2019). Bu sebeple öğrencilerin fen ve matematik alanlarındaki başarısızlık nedenleri araştırmacılar tarafından önemli görülmektedir. Alanyazın incelendiğinde, öğrencilerin öğrenmelerindeki başarısızlık ve yetersizliklerin sebepleri arasında ilgili bilim veya dersle ilgili korkuları yer almaktadır (Rodrigues, 2012). Öğrenciler fen, yabanc1 dil ve matematik derslerinde ve konularında diğer derslere göre daha fazla kaygı ve korku yaşamaktadır (Goetz, Frenzel, Pekrun, Hall \& Lüdtke, 2007; Hoffman, 2010; Jameson, 2010). Benzer şekilde biyoloji eğitiminde de öğrencilerin duygu ve hislerinin özellikle de kaygı, korku ve tutumlarının biyoloji dersi akademik başarısı üzerine etkili olduğu ifade edilmektedir (Morgan, 1992; Prokop, Kubiatko \& Fanoviková, 2008; Randler, Ilg \& Kern, 2005; Wai \& Khine, 2020). Ancak günümüz araştırmacılarının, çoğunlukla matematik korkusu üzerine odaklandığı biyoloji eğitiminde ise korku üzerine yeterince odaklanılmadığı görülmektedir (Başar \& Doğan, 2020; Fraser \& Honeyford, 2000; Green, 1999; Öztop \& Toptaş, 2017; Tobias \& Weissbrod, 1980; Whyte \& Anthony, 2012).

Korku bireylerin tehlikeli olarak algıladığg veya düşündüğü tehdit dolu durum, kişi, nesne, olay vb. karşısında gösterdiği duygusal tepkidir (Köknel, 2004; Lazarus, 1991). Korku durumunda birey huzursuzluk, kaygı, tedirginlik ve endişe yaşamakta ve dengesiz davranışlar göstermektedir (Burkovik \& Tan, 2006). Bireylerde korku oluşumu; çevre şartlarına, bireyin yaşantısına, uyaranların şiddetine, fizyolojik ve psikolojik duruma bağlıdır (Oguz, 2019). Pavlovun klasik koşullanma teorisi, insanların geliştirdiği bazı korku ve tutumların açılanmasında yardımcı olmaktadır (Mineka \& Zinbarg, 2006). Klasik koşullanma teorisi korku ve tutum ile öğrenme arasındaki ilişkiyi açıklamıştır. Bu teoride, örneğin bir bireyin arı sokması korkusu ile arıyı ilişkilendirmesi sonucu bireyin böceklere karşı korku geliştirdiği ifade edilmektedir (Ormrod, 2013). Bu doğrultuda öğrencilerin yaşantısında karşılaştığı olumsuz bir olay korku ve olumsuz tutum şeklinde ortaya çıkabilmektedir. Dolayısıyla öğrencilerin biyoloji korkusu ve tutumlarının gelişmesinde özellikle çocukluktan başlayarak geçirdiği günlük deneyimler ve biyoloji ve biyoloji dersi ile ilgili yaşantılarının etkili olduğu düşünülmektedir. Alanyazında biyolojide konuların içeriğine ve içeriğinde yer alan canlılara ilişkin sevgi ve nefretin de öğrenmeyi olumsuz etkilediği ifade edilmektedir (Prokop, Uşak, Erdoğan, Fancovicova \& Bahar, 2011). Bu nedenle biyoloji eğitimi noktasında biyoloji dersi korkusu ve sebepleri biyoloji dersine yönelik tutuma benzer şekilde önemlidir.

Tutum, bireylerin olgu, olay, durum vb. yönelik olumlu ya da olumsuz davranış gösterme eğilimidir (İnceoğlu, 2010). Tutum, birey davranışlarının önemli bir yordayıcısı olup birçok birey davranışlarını etkilemektedir (Anderson, 1988; Demirbaş \& Yağbasan, 2006; Morgan, 1995). Tutum, klasik koşullanma teorisinde açıklandığ gibi hoş deneyimlerle ilişkilendirilmiş objeler, kişiler, olaylar vb. olumlu değerlendirilirken, hoş olmayan yaşantılarla ilişkilendirilenler ise olumsuz olarak değerlendirilmektedir (Tavşancıl, 2010). Bireyler bilgileri ve olguları öğrendiği gibi olgulara yönelik tutumları da öğrenmektedir (Freedman, Sears \& Carlsmith, 1989). $\mathrm{Bu}$ durumda günlük yaşantı, çevre, sosyal ortam, ders etkinlikleri, laboratuvar 
çalışmaları vb. öğrencilerin biyoloji derslerine yönelik tutumlarının oluşumunda etkilidir (Chuang \& Cheng, 2003; Mutlu, 2006; Okereke \& Nzewi, 2020).

Öğrencilerin biyoloji dersine yönelik tutumları noktasında alanyazında birçok çalışma yer almaktadır. Bu çalışma sonuçlarına göre öğrencilerin biyoloji dersi tutumlarınının olumlu yada olumsuz olduğuna karar vermenin zorluğu dikkati çekmektedir. Örneğin, Gül ve Yeşilyurt (2010) öğrencilerin biyolojiyi önemli ve faydalı bir bilim olarak kabul etmelerine rağmen biyoloji öğretmenlerine ve biyoloji dersine karşı olumsuz tutum geliştirdiklerini ve biyoloji dersini zaman kaybı olarak gördüklerini belirtmişlerdir. Yapıcı (2015) ve Özarslan (2019) ise öğrencilerin biyolojiyi anlaşılmaz/katlanılmaz, zor ve karışık bir ders olarak algıladıklarını tespit etmişlerdir. Atik, Tan, Doğan ve Erkoç (2018) ile Ekici ve Hevedanlı (2010) öğrencilerin biyoloji dersine yönelik tutumlarının orta düzeyde ve Atik ve Erkoç (2015) ile Durdukoca ve Önel (2020) ise öğrencilerin biyoloji bilimi ve dersine yönelik tutumlarının pozitif olduğunu ortaya koymuşlardır. Örnek çalışma sonuçlarından da görüleceği üzere öğrencilerin biyoloji dersine yönelik tutumlarının belirlenmesi noktasında yeni çalışmalara ihtiyaç duyulmaktadır.

Alanyazında, biyoloji dersi öğrencilerin zor olduğuna inandığı, başarısız olduğu ve anlamakta güçlük çektiği derslerden biri olarak görülmektedir (Chuang \& Cheng, 2003; Durdukoca \& Önel, 2020; Etobro \& Fabinu, 2017; Staeck, 1995; Yeşilyurt \& Gül, 2008). Özellikle biyolojide genetik, solunum, hayvansal ve bitkisel dokular, fotosentez, sinir sistemi, mitoz ve mayoz hücre bölünmesi, bitkilerde üreme sistemi ve endokrin sistemler konularının öğrenciler tarafından en zor anlaşlan konular arasında olduğu tespit edilmiştir (Bahar, Johnstone \& Hansell, 1999; Chiappetta \& Fillman, 1998; Etobro \& Fabinu, 2017; Fauzi \& Mitalistiani, 2018; Güneş \& Güneş, 2005; Johnstone \& Mahmoud, 1980; Lazorowitz \& Penso, 1992; Wai \& Khine, 2020). Bulgular beraber değerlendirildiğinde biyoloji dersinde yaşanan zorluk ve güçlüklerin öğrencilerde olumsuz tutumlara ve biyoloji korkusu gelişiminde etkili olabileceği yorumlanmıştır. $\mathrm{Bu}$ düşünce doğrultusunda matematik korkusu konusunda olduğu gibi öğrencilerin biyoloji korkusu ve sebepleri noktasında da yeni çalışmalara gerek duyulmaktadır. Araştırma sonuçları, eğitimcilere ve araştırmacılara biyoloji dersi etkinliklerinin hazırlanması, öğrencilerin biyoloji dersine yönelik olumlu duygular geliştirmesi ve başarısının artırılmasına yardımc1 olacaktır.

\subsection{Araştırmanın Amacı}

Araştırmada, 9. ve 10. sınıf ortaöğretim kız öğrencilerinin biyoloji korkusu ve sebeplerine ilişkin görüşleri ile biyolojiye yönelik tutumlarının belirlenmesi amaçlanmıştır. $\mathrm{Bu}$ amaç doğrultusunda aşağıdaki üç soruya cevap aranmıştır:

1. Öğrencilerin biyoloji korkusu ile ilgili düşünceleri nelerdir?

2. Öğrencilerin biyoloji korkusunun sebeplerine ilişkin düşünceleri nelerdir?

3. Öğrencilerin biyoloji bilimi ve biyoloji dersine yönelik tutumları nasıldır?

\section{Yöntem}

\subsection{Araştırma Modeli}

Çalışmada betimsel araştırma yaklaşımı benimsenmiştir (Büyüköztürk, Çakmak, Akgün, Karadeniz \& Demirel, 2018). Bu yaklaşımın tercih edilmesi, betimsel araştırmaların olgu yada olayları doğal ortamında herhangi bir müdahale yapmaksızın ve doğası bozulmadan incelemeye firsat sunmasından kaynaklanmaktadır (Çepni, 2014). Verilerin elde edilmesinde nitel ve nicel araştırma yöntemlerinin eş zamanlı olarak kullanıldığı çeşitleme yöntemi uygulanmıştır (Büyüköztürk vd., 2018). Bu yöntemde nicel ve nitel veriler beraber toplanarak analiz edilir, 
veri analizi her iki yöntemde ayrı ayrı yapılır ve yorumlama birleştirilerek gerçekleştirilir. Bu yöntem araştırmada elde edilen bulguları doğrulamak ve güçlendirmek için faydalı görülmektedir (Creswell, 2003).

\subsection{Katılımcilar}

Çalışma, 2015-2016 akademik yılı bahar dönemi sonunda gerçekleştirilmiştir. Katılımcılar, Marmara bölgesinin bir ilçe merkezinde mesleki ve teknik anadolu lisesine devam eden toplam $70 \mathrm{kız}$ öğrenciden oluşmaktadır. Çalışmaya 9. ve 10. sınıf öğrencileri dâhil edilmiştir. Bu sınıflar, zorunlu olarak biyoloji dersi görmeleri sebebiyle tercih edilmiştir. Çalışma grubu, kolay ulaş1labilir durum örneklemesi yöntemi ile belirlenmiştir (Büyüköztürk vd., 2018). Öğrenciler çalışmaya gönüllü olarak dahil olmuşlardır. Ayrıca ilgili otoritelerden gerekli izinler alınmıştır. Katılımcılara ait öğrenci sayıları Tablo 1'de sınıf düzeyi değişkenine göre sunulmuştur:

Tablo 1. Öğrencilerin Okul ve Sınıflarına Göre Betimsel İstatistik Bilgileri

\begin{tabular}{cc}
\hline Sinıf & N \\
\hline 9. sinif & 36 \\
10. sinif & 34 \\
\hline Toplam & 70 \\
\hline
\end{tabular}

\subsection{Veri Toplama Araçları ve Verilerin Toplanması}

Araştırma verileri, Biyoloji Bilimine ve Dersine Yönelik Tutum Ölçeği ve Biyoloji Korkusu Anketi uygulanarak elde edilmiştir.

\subsubsection{Biyoloji Bilimine ve Dersine Yönelik Tutum Ölçeği}

Ölçek, Atik, Kayabaşı, Yağcı ve Erkoç (2015) tarafından ortaöğretim öğrencilerinin Biyoloji bilimine ve dersine yönelik tutumlarının belirlenmesi amacıyla geliştirilmiştir. Ölçeğin Cronbach Alpha İç Tutarlılık Katsayısı .928 olarak tespit edilmiştir. Biyoloji bilimine yönelik ilgi, biyoloji dersinden zevk alma ve kaygı alt boyutlarından oluşmaktadır. Ölçek, 13 olumlu ve 10 olumsuz ifadenin yer aldığ 1 toplam 23 maddeden oluşmaktadır. 5'li likert tipinde hazırlanmış bu ölçekte kategoriler "Kesinlikle Katılıyorum", "Katılıyorum", "Kararsızım", "Katılmıyorum" ve "Kesinlikle Katılmıyorum" şeklinde düzenlenmiştir.

\subsubsection{Biyoloji Korkusu Anketi}

Öğrencilerin biyoloji korkusu ve sebeplerine yönelik düşüncelerinin belirlenmesi amacyyla araştırmacı tarafından hazırlanmıştır. Ankette "Biyoloji ile ilgili korkunuz var mı? Cevabınız evet ise biyoloji ile ilgili korkularınız nelerdir?" ve "Biyoloji ile ilgili korkularınızın sebepleri nelerdir? Nelerden kaynaklandığını düşünüyorsunuz? (Anlamadı̆̆ın konular, konuların içeriği, yaşadı̆̆ın olumsuz olaylar, sevmediğin ögretmen, yanlış biyoloji eğitimi, vb.)" olmak üzere iki açık uçlu soru yer almaktadır. Açık uçlu sorularda boş bırakılan yere öğrencinin kendi görüşlerini yazması istenmiştir.

Ankette, öğrencilerden "Biyoloji ile ilgili korkularınızı çizerek resmediniz. Çizimlerinizi kısaca açıklayınız?" ifadesini cevaplamaları istenmiştir. Çizme-yazma tekniği bireylerin görüşlerinin açığa çıkarılmasında yaygın olarak kullanılmaktadır (Harrison \& Treagust, 2000; Özarslan \& Çetin, 2018). Hem açık uçlu sorular hem de çizme-yazma tekniği araştırmacının beklemediği cevaplara ulaşabilmesi ve konu hakkında daha geniş ve ayrıntılı bilgi elde edilmesinde etkilidir (Büyüköztürk vd., 2018; White \& Gunstone, 1998). Anket ile ilgili olarak bir biyoloji eğitimcisi akademisyen ve iki biyoloji öğretmenin görüsslerine başvurulmuştur. Türk Dili ve Edebiyatı 
öğretmeni tarafından gözden geçirilen anket, anlam ve dil bilgisi yönünden düzenlenmiştir. Anket, kullanımı öncesi 10 öğrenciye uygulanmış ve son düzenlemeleri yapılmıştır.

Çalı̧̧mada katılımcılara Biyoloji Bilimine ve Dersine Yönelik Tutum Ölçeği ve Biyoloji Korkusu Anketi birlikte uygulanmıştır. Katılımcılara uygulamanın araştırma amaçlı olduğu ve bir sınav olmadığı açıklanmıştır. Öncelikle katılımcılara Biyoloji Bilimine ve Dersine Yönelik Tutum Ölçeğini tamamlamaları için 10 dakika süre verilmiştir. Sonrasında katılımcılara araştırmacı tarafından çizme-yazma tekniği ve açık uçlu soruların nasıl cevaplanacağ konusunda bilgi verilmiş ve uygulama yapılmıştır. Anketin tamamlanması için öğrencilere 15 dakika süre verilmiştir.

\subsection{Verilerin Analizi}

Çalışmada öğrencilerin Biyoloji Bilimine ve Dersine Yönelik Tutum Ölçeği puanlarının dağılım normalliğinin denetlenmesi için Basıklık (Skewness) ve Çarpıklık (Kurtosis) testleri uygulanmıştır. Ölçek puanlarının normal dağılıp dağılmadığına yönelik yapılan basıklık ve çarpıklık değerleri incelenmiştir. Sonuçta ölçek puanlarının çarpıklık ve basıklık değerlerinin +1 ile -1 arasında değişim gösterdiği belirlenmiş ve verilerin normal dağılım gösterdiğine karar verilmiştir (Büyüköztürk vd., 2018). Öğrencilerin biyoloji bilimine ve dersine yönelik tutumlarının belirlenmesi için betimsel analizler yapılmıştır.

Nitel verilerin analizinde içerik analizi tekniği kullanılmıştır. Araştırmacı içerik analizi tekniğiyle anket verilerini açıklayabilecek kavramlara ve kavramlar arasındaki mevcut ilişkilere ulaşmayı amaç edinmiştir (Yıldırım \& Şimşek, 2011). Veri analizi için öğrencilerin cevap kâğıtları 1'den 70'e kadar numaralandırılmıştır. Öncelikle veriler detaylı olarak gözden geçirilmiş, her öğrenci açıklaması ve çizim içeriği ayrıntılı olarak analiz edilmiştir. Araştırma soruları doğrultusunda öğrenci açıklamaları ve çizimlerinde benzer ve farklı ifadeler değerlendirilmiştir. Birbirine benzeyen açıklama ve çizimler belirlenmiş, ifade ettikleri anlamlar kodlanmış ve ilişkili temalar altında düzenlenmiştir. Belirlenen temaların anlaşılabilir olması için genel ifadeler kullanılmıştır.

Verilerin kodlanması, araştırmacı ve içerik analizi konusunda deneyimli bir doktora öğrencisi tarafından ayrı ayrı gerçekleştirilmiştir. Kodlama yapanlar, görüş ayrılığı yaşanılan noktaları tekrar gözden geçirmiş ve tartışmışlardır. Katılımcıların her soruya verdiği birden fazla cevaplar değerlendirmeye alınarak kodlanmıştır. Bu sebeple katılımcıların verdiği cevapların frekansları katılımc1 sayısından fazla olabilmektedir.

\subsection{Geçerlik ve Güvenirlik}

Çalışmada Biyoloji Bilimine ve Dersine Yönelik Tutum Ölçeği puanlarının Cronbach Alpha güvenirlik katsayıs1 .943 olarak bulunmuştur. Nitel verilerin güvenirlilik durumu, iki kodlayıcıdan elde edilen veriler kullanılarak Miles ve Huberman (2002) tarafindan önerilen kodlayıcı güvenirliği uyum yüzdesi formülü (Güvenirlik = (Uyuşum olan kodların sayısı) / (Uyuşum olan ve olmayan kodların toplam sayısı) x 100) ile hesaplanmıştır. İki farklı kodlayıcının uyuşumunun $\% 90$ olduğu ve güvenirlik için yeterli olduğu belirlenmiştir (Miles \& Huberman, 2002). Çalı̧̧mada katılımcıların cevaplarına ait bazı örnekler katılımcı numarası verilerek, “ ..." $\left(\mathrm{K}_{41}\right)$ şeklinde sunulmuştur (Yıldırım \& Şimşek, 2011). Ayrıca çalışma sonuçlarının geçerliğini sağlamak amacıyla, verilerin kodlanması ve analizi detaylı olarak anlatılmıştır (Hruschka, Schwartz, John, Picone-Decaro, Jenkins \& Carey, 2004). Çalışmada ham veriler, analiz aşamasında yapılan kodlamalar ve konuyla ilgili gerekli tüm dokümanlar uzman incelemesi amaciyla saklanmaktadır. 
Öğrencilerin Biyoloji Korkusu ve Biyolojiye Yönelik Tutumları

\subsection{Etik Kurul İzin}

Yapılan bu çalışmada bilimsel, etik ve alıntı kurallarına uyulduğu, toplanan veriler üzerinde herhangi bir tahrifatın yapılmadığı, karşılaşılacak tüm etik ihlallerde "Asya Öğretim Dergisi ve Editörünün” hiçbir sorumluluğunun olmadığı, tüm sorumluluğun Sorumlu Yazara ait olduğu ve bu çalışmanın herhangi başka bir akademik yayın ortamına değerlendirme için gönderilmemiş olduğu sorumlu yazar tarafindan taahhüt edilmiştir. Bu çalışmanın verileri 2020 yılından önce toplandığı için etik kurul onayı alınmamıştır.

\section{Bulgular}

Biyoloji Korkusu Anketi ve Biyoloji Bilimine ve Dersine Yönelik Tutum Ölçeği'inden elde edilen bulgular bu bölümde sunulmuştur.

\section{1. Öğrencilerin Biyoloji Korkuları ve Sebeplerine İlişkin Bulgular}

Araştırma bulgularında öğrencilerin çoğunluğunun biyoloji korkularına sahip olduğu (63) ve bazı öğrencilerde ise biyoloji korkularının olmadığı (7) belirlenmiştir. Öğrenciler tarafından belirtilen biyoloji korkuları ve sebeplerine ilişkin açıklama ve çizimlerine ait bulgular Tablo 2' de sunulmuştur:

Tablo 2. Öğrencilerin Biyoloji Korkusu Sebepleri

\begin{tabular}{|c|c|c|c|}
\hline Temalar & Kodlar & $\begin{array}{c}\text { Açılklama } \\
\text { f } \\
\end{array}$ & $\begin{array}{c}\text { Çizim } \\
\mathbf{f}\end{array}$ \\
\hline \multirow{6}{*}{$\begin{array}{l}\text { Başarı } \\
\text { Durumundan } \\
\text { Kaynaklanan } \\
\text { Korkular }\end{array}$} & Konuları anlayamama & 29 & 14 \\
\hline & Başarısız olma & 28 & 8 \\
\hline & Sinavlarda yapamama & 11 & - \\
\hline & Öğrendiklerini karıştırma & 4 & - \\
\hline & Dikkati toplayamama & 3 & - \\
\hline & Öğrendiklerini unutma & 2 & 3 \\
\hline \multirow{12}{*}{$\begin{array}{l}\text { Biyoloji } \\
\text { Konularından } \\
\text { Kaynaklanan } \\
\text { Korkular }\end{array}$} & $\begin{array}{l}\text { Konularda tiksindiği ve korktuğu canlıların olması } \\
\text { (Bağırsak solucanları, böcekler, sürüngenler, } \\
\text { mantarlar, hastalık yapıcı ve parazit canlılar gibi.) }\end{array}$ & 15 & 32 \\
\hline & Konuların karışık ve zor olması & 14 & 1 \\
\hline & Konuların ilgi çekici olmaması & 6 & 3 \\
\hline & Biyoloji/Konuları sevmeme & 4 & 3 \\
\hline & İnsan vücudu (Kemikler, deri, hücreler) & 3 & 1 \\
\hline & Kalıtım/kromozom & 2 & 8 \\
\hline & Kalıtsal hastalıklar & 2 & 2 \\
\hline & Konuların gelecekte ne işe yarayacağını bilmeme & 2 & - \\
\hline & Matematiksel işlemler ve soru çözümü & 1 & - \\
\hline & Biyosfer konusu & 1 & - \\
\hline & Konulardaki yabancı kavramlar & 1 & - \\
\hline & Eşeyli ve eşeysiz üreme/ mitoz ve mayoz konuları & 1 & 3 \\
\hline \multirow{5}{*}{$\begin{array}{l}\text { Ders } \\
\text { İşlenişinden } \\
\text { Kaynaklanan } \\
\text { Korkular }\end{array}$} & Derslerin ilgi çekici işlenmemesi/sıkıcı olması & 5 & 2 \\
\hline & Derslerde öğretmenle anlaşamama/sevmeme & 4 & 1 \\
\hline & Derslerde sınıf ortamından çekinme/utangaç olma & 3 & 2 \\
\hline & Dersleri laboratuarda işlememe & 2 & - \\
\hline & Derslerdeki gürültülü sınıf ortamı & - & 1 \\
\hline
\end{tabular}

Tablo 2'ye göre öğrencilerin biyoloji korkusu sebeplerine ilişkin düşünceleri "Başarı Durumundan Kaynaklanan Korkular", "Biyoloji Konularından Kaynaklanan Korkular" ve "Ders İşlenişinden Kaynaklanan Korkular" olmak üzere 3 temada düzenlenmiştir. "Başarı 
durumundan kaynaklanan korkular" temasında öğrencilerin biyoloji korkusu sebeplerinin "Konuları anlayamama" (A, 29; Ç, 12) ve "Başarısız olma" (A, 28; Ç, 8) ve "Sınavlarda yapamama" (A,11) şeklinde olduğu belirlenmiştir. "Biyoloji konularından kaynaklanan korkular" temasında öğrencilerin biyoloji korkusu sebeplerinin "Konularda tiksindiğim ve korktuğum canlıların olması" (A, 15; Ç, 32), "Konuların karışık ve zor olması" (A, 14) ve "Biyoloji ve konuları sevmeme" (A, 4; Ç, 3) şeklinde olduğu belirlenmiştir. "Ders işlenişinden kaynaklanan korkular" temasında öğrencilerin korkularının sebepleri arasında "Derslerin ilgi çekici işlenmemesi" (A, 5; Ç, 2) ve "Derslerde öğretmenle anlaşamama ve sevmeme" (A, 4; Ç, 1) şeklinde olduğu ifade edilmiştir. Katılımcıların görüşlerine ilişkin alıntılar şu şekildedir:

Sinavlarda yapamama ve dersten kalma korkum var." $\left(\mathrm{K}_{30}\right)$

Başarısı olmaktan korkuyorum. $\left(\mathrm{K}_{40}\right)$

Biyoloji konuları sıkıcı olduğu için. $\left(\mathrm{K}_{14}\right)$

Anlamadı ̆̆ım konular olduğu zaman korkuyorum. $\left(\mathrm{K}_{68}\right)$

Dersi sevmiyorum. Anlamadığım konuları düşünüyorum ve dikkatimi toplayamıyorum. $\left(\mathrm{K}_{51}\right)$

Canlılar âlemi ünitesindeki sürüngenler ve bağırsak solucanı beni korkutuyor. $\left(\mathrm{K}_{38}\right)$

Kalttsal hastalıklardan korkuyorum. $\left(\mathrm{K}_{49}\right)$

Katılımcıların çizimlerine ilişkin alıntılar şu şekildedir:

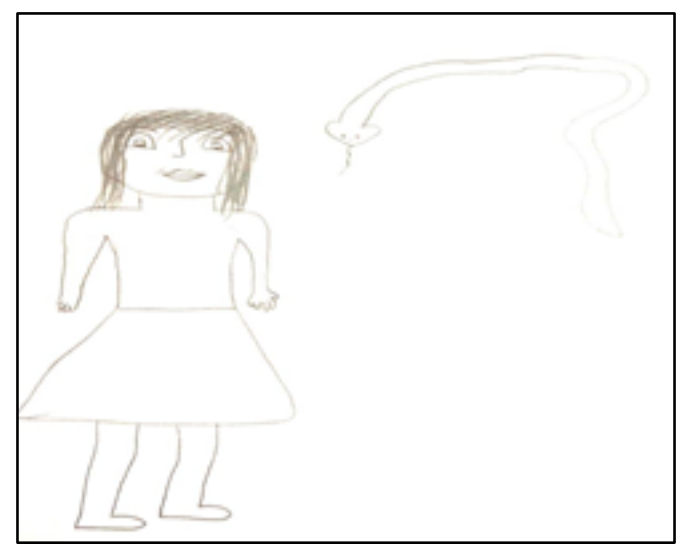

Şekil 1. Konu edilen canlılara ilişkin korku $\left(\mathrm{K}_{53}\right)$

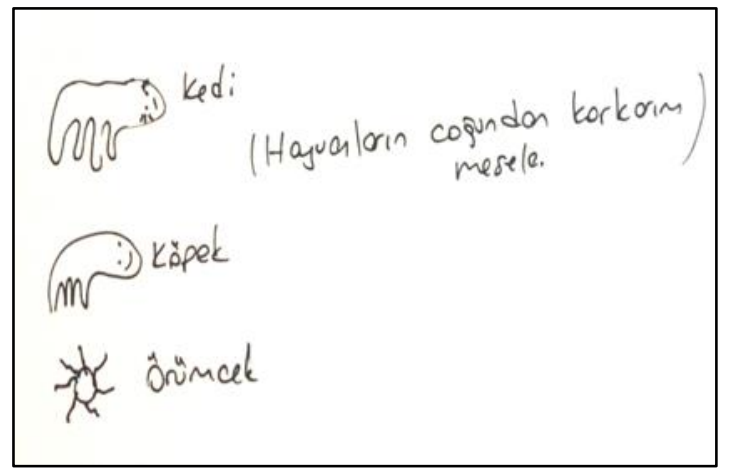

Şekil 3. Konu edilen canlılara ilişkin korku $\left(\mathrm{K}_{5}\right)$

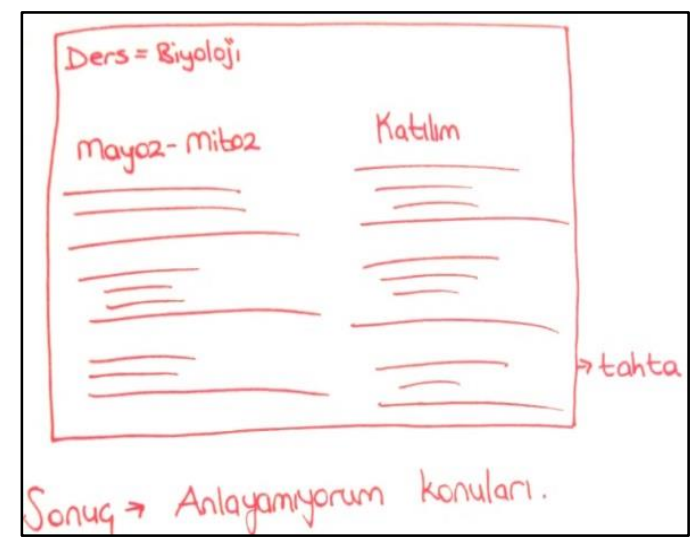

Şekil 2. Konuları anlayamama korkusu $\left(\mathrm{K}_{33}\right)$

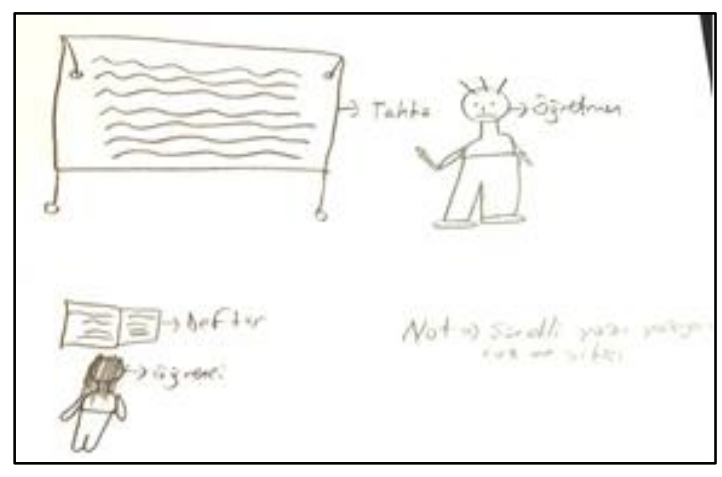

Şekil 4.Dersin sıkıcı işlenişi $\left(\mathrm{K}_{19}\right)$ 


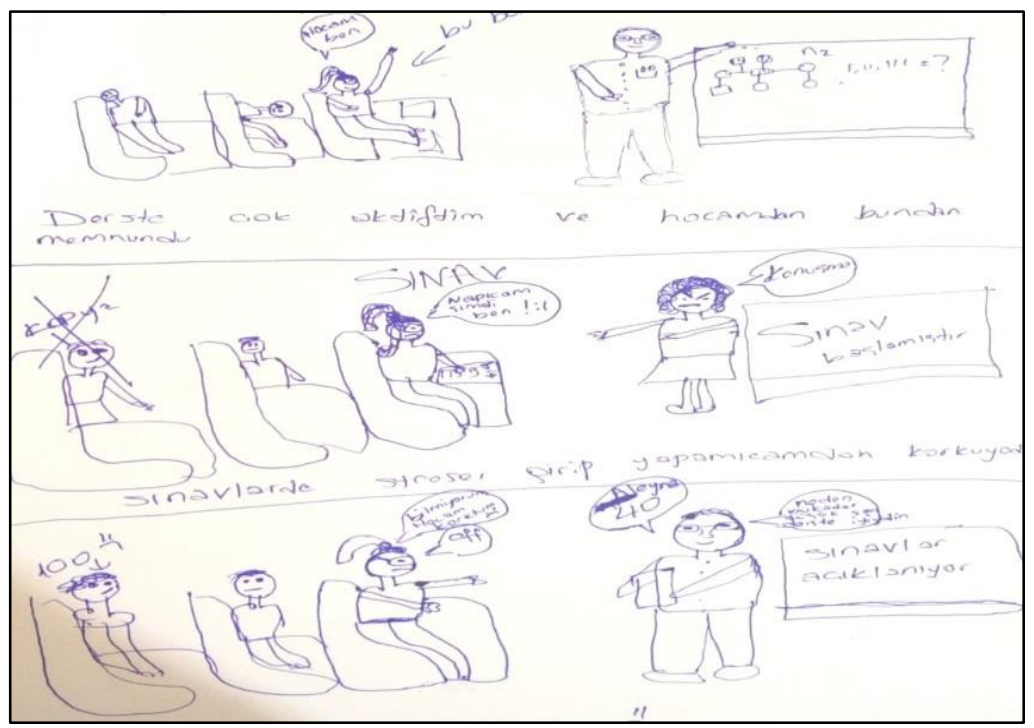

Şekil 5. Sınavda başarısız olma korkusu $\left(\mathrm{K}_{45}\right)$

\section{2 Öğrencilerin Biyoloji Bilimine ve Dersine Yönelik Tutumlarına İlişkin Bulgular}

Öğrencilerin Biyoloji Bilimine ve Dersine Yönelik Tutum Ölçeği’nden elde edilen puanların betimsel istatistik ve merkezi eğilim sonuçları Tablo 4'te sunulmuştur:

Tablo 3. Biyoloji Bilimine ve Dersine Yönelik Tutum Ölçeği Puanlarının Betimsel İstatistik ve Merkezi Eğilim Sonuçları

\begin{tabular}{llccccc}
\hline Ölçek & \multicolumn{1}{c}{ Boyutlar } & N & $\overline{\mathbf{X}}$ & Ss & Basıklık & Çarpıklık \\
\hline \multirow{4}{*}{ Tutum } & Genel Tutum & 70 & 2.87 & .905 & .257 & -.596 \\
& Biyoloji bilimine yönelik ilgi alt boyutu & 70 & 2.94 & 1.026 & -.161 & -.908 \\
& Biyoloji dersinden zevk alma alt boyutu & 70 & 2.90 & 1.112 & .128 & -.837 \\
& Biyoloji dersinden kaygı duyma alt boyutu & 70 & 2.73 & .980 & .361 & -.086 \\
\hline
\end{tabular}

Tablo 3'e göre, Biyoloji Bilimine ve Dersine Yönelik Tutum Ölçeği tutum puanlarının genel tutum, biyoloji bilimine yönelik ilgi, biyoloji dersinden zevk alma ve biyoloji dersinden kayg1 duyma tutum puanlarının düşük düzeyde $(\bar{X}=2.87, \bar{X}=2.94, \bar{X}=2.90, \bar{X}=2.73)$ olduğu belirlenmiştir. $\mathrm{Bu}$ sonuçlara göre öğrencilerin biyoloji bilimine ve dersine yönelik tutum puanlarının, biyoloji bilimine yönelik ilgi, zevk alma ve kaygı alt boyutu puanlarının düşük düzeyde olduğu söylenilebilir.

\section{Tartışma ve Sonuçlar}

Araştırmada, 9. ve 10. sınıf kız ortaöğretim öğrencilerinin biyoloji korkuları, sebepleri ve biyolojiye yönelik tutumlarının belirlenmesi amaçlanmıştır. Araştırma sonucunda öğrencilerin çoğunluğunun biyoloji korkularına sahip olduğu tespit edilmiştir. Biyoloji korkularının sebeplerine ilişkin öğrenci açıklama ve çizimlerinde çoğunlukla konuları anlayamama, başarısız olma, sınavlarda zorlanma ve konuların karışık ve zor olması sebepleri ifade edilmiştir. Bu sonuçlar, alanyazında biyoloji dersinin öğrencilerin zor olduğuna inandığ 1 ve anlamakta güçlük çektikleri derslerin başında geldiği araştırma bulguları ile benzerlik göstermektedir (Ataş, 2018; 
Chuang \& Cheng, 2003; Durdukoca \& Önel, 2020; Etobro \& Fabinu, 2017; Güneş \& Güneş, 2005; Staeck, 1995; Yapıcı, 2015; Yeşilyurt \& Gül, 2008). Sonuç olarak öğrencilerin biyoloji dersinde zorlanması onlarda biyoloji korkularına sebep olabileceği şeklinde yorumlanmıştır.

Araştırma sonuçlarında, biyoloji korkularının sebeplerine ilişkin öğrenci açıklama ve çizimlerinde derslerin ilgi çekici işlenmemesi, öğrenci-öğretmen iletişiminin iyi olmaması, derslerin laboratuvarda işlenmemesi ve gürültülü sınıf ortamı sebepleri belirlenmiştir. $\mathrm{Bu}$ sonuçlar alanyazında öğrencilerin biyoloji konularında zorlanma sebeplerinin çoğunlukla derslerde deney yapılmaması, yetersiz öğretim materyali kullanımı, konuların ezbere dayalı olarak işlenmesi gibi sonuçlarla örtüşmektedir (Etobro \& Fabinu, 2017; Güneş, Şener, Germi \& Can, 2013; Tekbıyık \& Akdeniz, 2008; Vekli, 2018; Wai \& Khine, 2020). Sonuç olarak, öğrencilerin biyoloji dersinin işlenmesi sürecinde oluşan bazı sorunların onlarda biyoloji korkularına sebep olabileceği düşülmektedir. Bu sebeple biyoloji derslerinde biyoloji konuları işlenirken öğrenilenlerin yaşantımızda kullanım şekilleri, öğrenci ilgisini ve dikkatlerini çekecek şekilde etkinliklerin planlanması, sınıf disiplinin sağlanması ve biyoloji de deneysel uygulamalara ağırlık verilmesi faydalı olabilir.

Araştırma sonuçlarında, öğrencilerin açıklama ve çizimlerinde biyoloji dersi konularında böcekler, bakteriler, bağırsak solucanı, parazitler vb. ile ilgili konu içeriklerinin biyoloji korkularının sebepleri arasında yer aldığı tespit edilmiştir. Alanyazında öğrencilerin böcek, köpek, yarasalar vb. hayvanlara karşı korku duyduğu (Arrindell, 2000; Ay Solmaz, 2017; Davey, 1994; Kubiatko, 2012; Moss, 2019; Oğuz, 2019; Robins \& Regier, 1991), y1lan ve örümceklere karşı daha olumsuz tutumlar geliştirdiği (Prokop, Fanşoviková \& Kubiatko 2009; Prokopvd., 2008; Prokop \& Tunnicliffe, 2008; Özel, Prokop \& Uşak, 2009) ifade edilmiştir. Ayrıca Türk öğrencilerin omurgasız hayvanlara yönelik yüksek düzeyde korku, nefret ve tehlike algısına sahip olduğu belirlenmiştir (Prokop vd., 2011). Okereke ve Nzewi (2020) ise öğrencilerin hayvan diseksiyonu, kan ve kan kokusuna karşı da korkularının varlığını ortaya koymuştur. Alanyazında ortaya konulan canlılara yönelik duyulan korku ve olumsuz tutumlarla bu araştırma sonuçları benzerlik göstermektedir. Öğrencilerin bu korkularının önemli bir kısmının çocukluktan geldiği düşünülmektedir. Çünkü Oghii (2015) ve Oğuz (2019) çocuklarda en çok tekrarlanan korkuların hayvanlara (yılan, böcek, köpek, vs.) yönelik korkular olduğu ifade edilmektedir. Bu bulgulara ek olarak öğrencilerin kalıtsal hastalıklar, hastalık yapıcı parazitler ve bağırsak solucanı gibi canlılara yönelik korkularının varlığı belirlenmiştir. Çocukların hayvanlara karşı korkuları ebeveyn davranışlarından kaynaklanabildiği gibi çocukların hayvanlarla yaşadığı olumsuz deneyimlerden de kaynaklanabilmektedir (Oğuz, 2019). Bunlara ek olarak, kız öğrencilerin hastalıklardan ve hastalık yapıcı canlılardan korunma isteği de etkilidir (Erten, 2008; Prokop vd., 2011). Burada önemli olan nokta; öğrencilerin bir canlıyı sevme, tiksinme veya beğenmeme durumlarının biyolojide bu canlıları içeren konuları öğrenmelerini olumsuz etkilemesidir (Dervişoğlu, Menzel, Soran \& Boegeholz, 2009). Dolayısıyla biyoloji ders içeriklerinde yer alan canlılara ilişkin korkuların öğrencilerin biyoloji dersindeki öğrenmelerini ve gelecekteki biyoloji başarılarını olumsuz etkileyeceği düşünülmektedir. $\mathrm{Bu}$ sebeple biyoloji etkinliklerinin hazırlanmasında öğrencilerin canlılara ilişkin hassasiyetleri dikkate alınmalıdır. Bu sorunların aşılması için hastalık yapıcı etkenlerden nasıl korunabileceği öğrencilerle daha ayrıntılı tartışılabilir. Korku duyulan canlıların öğrenciler tarafından daha iyi tanınması ve bilgi edinmeleri için etkinlikler planlanabilir. Öğrencilerin korku duyduğu hayvanlara yönelik okul dışı öğretim uygulamaları düzenlenebilir. Bakteriler, virüsler, parazit canlılar, örümcekler, yılanlar vb. korku duyulan canlıların "kötü, zararl1, korkunç ve tiksindirici" özelliklerinden farklı olarak bu canlıların ekosistem açısından dengeleyici işlevi ve etkinliği biyoloji derslerinde konu edilebilir. Alanyazında konu hakkında en fazla bilgiye ve olumlu tutuma sahip öğrencilerin biyoloji derslerinde canlı hayvanların kullanıldığı derse katılan öğrenciler olduğu belirtilmektedir (Tomažič, 2008). Ayrıca Acarlı ve 
Öğrencilerin Biyoloji Korkusu ve Biyolojiye Yönelik Tutumları

Acarlı (2020) öğrencilerin biyolojiye yönelik kaygılarının azaltılmasında, ilgi ve olumlu tutumun artırılmasında öğrencilerin hayvanları yakından tanımasının, evcil hayvan sorumluluğu almasının ve konuların sınıf ortamına getirilebilecek evcil hayvanlarla ilişkilendirilmesinin etkili olabileceğini belirtmiştir. Bu nedenle, biyoloji eğitimlerinde konuların uygunluğuna göre derslere canlı hayvanlar getirilebilir ve öğrencilerle bire bir etkileşimleri sağlanabilir. Bu şekilde canlılara yönelik korkuları azaltılabilir. Günümüz teknolojilerinden artırılmış gerçeklik ve sanal gerçeklik gibi üç boyutlu modellemeleri içeren teknolojiler yardımıyla öğrencilerin bu canlıları daha iyi tanıması ve olumlu yaşantılar elde etmesi sağlanabilir. Ayrıca ileri düzeydeki korku sorunları için rehberlik ve psikolojik danışmanlık gibi farklı disiplinlerden yardım alınabilir.

Araştırma sonuçlarında, öğrencilerin açıklama ve çizimlerinde biyoloji korkularının sebepleri arasında kalıtım, insan vücudu, kemikler, deri, hücre, kromozom, eşeyli ve eşeysiz üreme, mitoz ve mayoz hücre bölünmesi ifadelerinin yer aldığı belirlenmiştir. Bu sonuçlar, öğrencilerin biyoloji derslerinde öğrenmekte zorlandığı konuların biyoloji korkularına sebep olduğunu ortaya koymaktadır. Çünkü alanyazında öğrencilerin genetik, solunum, sinir sistemi, düzenleyici ve denetleyici sistemler, hücre bölünmesi, dokular (Bahar vd., 1999; Chiappetta \& Fillman, 1998; Fauzi \& Mitalistiani, 2018; Fauzi \& Fariantika, 2018; Güneş \& Güneş, 2005; Johnstone \& Mahmoud, 1980; Lazorowitz \& Penso, 1992; Wai \& Khine, 2020) gibi konular1 anlamakta zorlandıkları yönündeki araştırma sonuçları ile bu araştırma sonuçları benzerlik göstermektedir. $\mathrm{Bu}$ sebeple öğrencilerin zorlandığı konular günlük yaşamla daha fazla ilişkilendirilebilir ve deneysel çalışmalara daha fazla ağırlık verilebilir. Konuların öğretiminde proje çalışmaları ve sorgulayıcı öğrenme gibi öğrencilerin ilgisini geliştirebilecek ve öğrencinin daha aktif rol almasını sağlayacak öğrenme yöntem ve tekniklerine yer verilebilir.

Araştırma sonuçlarında öğrencilerin biyoloji bilimine ve dersine yönelik tutum ölçeği puanlarının düşük düzeyde olduğu belirlenmiştir. Ayrıca öğrencilerin biyoloji dersine yönelik ilgi ve biyoloji dersinden zevk alma puanlarının da düşük düzeyde olduğu tespit edilmiştir. Bu sonuçlar, öğrencilerin biyoloji bilime ve biyoloji dersine yönelik tutumlarının yeterli düzeyde olmadığı, biyoloji dersine yeterince ilgi duymadıkları ve derslerin işlenmesinde yeterince zevk almadıkları şeklinde yorumlanmıştır. Bu çalışma bulguları alanyazında, Gül ve Yeşilyurt (2010), Harman ve Şeker (2019), Özarslan (2019) ile Yapıcı (2015) çalışmalarında ortaya konulan öğrencilerin biyoloji dersine yönelik tutumlarının düşük düzeyde olduğu sonucu ile örtüşmektedir. Ayrıca çalışma sonuçlarında, öğrencilerin açıklama ve çizimlerinde dersin işlenişindeki sorunlara vurgu yaptıkları, biyoloji öğretmenleri ile yaşadıkları iletişim sorunları, biyoloji ders işlenişinin ilgi çekici olmaması ve derste sıkıldıkları gibi olumsuzlukları ortaya koyduğu belirlenmiştir. Bu sonuçlar beraber değerlendirildiğinde öğrencilerin biyoloji derslerinin işleniş şekli, sınıf ortamının öğrencilerin ilgi ve dikkatlerini çekici olmaması ve dersin sürekli sınıf ortamında işlenmesi gibi nedenlerden dolayı biyoloji dersinin sıkıcı geçmesine ve öğrencilerin zevk almamasına neden olabileceği düşünülmektedir. Sonuçta belirtilen sorunlar öğrencilerde biyoloji dersine yönelik olumsuz tutumlar geliştirebilir. Bu noktada, biyoloji dersleri öğrencilerin ilgi ve dikkatini çekmeli, araştırmaya ve düşünmeye sevk etmeli, eğlendirici olmalı, laboratuvar çalışmaları arttırılmalı, sınıf dışı öğrenme uygulamalarına yer verilmeli, öğrenci merkezli olarak düzenlenecek biyoloji etkinlikleri yaparak ve yaşayarak öğrenmeyi teşvik etmelidir.

Araştırma sonuçlarında, öğrencilerin açıklama ve çizimlerinde biyolojiyi ve konularını sevmedikleri, konuların ilgi çekici olmadığı, konuların zor ve karmaşık olduğu ifade edilmektedir. Ayrıca öğrencilerin biyoloji bilimine yönelik ilgi ve biyoloji dersinden zevk alma tutum puanlarının düşük düzeyde olduğu da belirlenmiştir. Bu bulgular, Harman ve Şeker (2019) çalışmasında öğrencilerin biyoloji deneylerinden sıkıldıkları, Gül ve Yeşilyut (2010) ile Yılmaz, Çimen, Karakaya ve Üçüncü (2018) öğrencilerin biyoloji dersini zaman kaybı olarak değerlendirdiği, biyoloji dersine karşı ön yargılı oldukları ve bu dersi sevmedikleri araştırma 
sonuçları ile örtüşmektedir. Öğrencilerin, biyoloji dersine çalışırken strese girdikleri, kısa sürede unutulacak ve sadece ezberlenecek bir ders olarak gördükleri ve biyoloji dersine sadece sinav için çalıştıkları ifade edilmiştir (Özbaş, 2016; Wai \& Khine, 2020). Ancak alanyazında öğrencilerin biyoloji dersine yönelik tutumlarının olumlu düzeyde olduğunu ortaya koyan birçok çalışmada bulunmaktadır (Atas, 2018; Atik \& Erkoç, 2015; Atik vd., 2018; Durdukoca \& Önel, 2020; Ekici \& Hevedanl1, 2010; Prokop, Prokop \& Tunnicliffe, 2007). Bu sonuçlara göre, derse yönelik tutum ile ders başarısı arasında doğru orantılı bir ilişki olduğu bilindiğinden (Dhindsa \& Chung, 2003; Ekici \& Hevedanl1, 2010; Mutlu, 2006; Osborne, Simon \& Collins, 2003), öğrencilerin biyoloji dersine yönelik başarılı olmaları için biyoloji ve biyoloji dersine yönelik tutumlarının geliştirilmesi ve biyoloji korkularının önlenmesine çalışılmalıdır. Öğrencilerin biyoloji dersini daha fazla sevmeleri için öğrenciler ezberden uzak durmalı, konular gerekirse tartışılmalı ve öğrenilenler günlük yaşantı ile ilişkilendirilmelidir.

Eğitimciler biyoloji dersinin daha iyi anlaşılması ve kalıcılığının artırılması için biyoloji konularının öğretiminde öğrenilenlerle günlük yaşamı ilişkilendirebilir ve deneysel uygulamalara ağırlık verebilirler. Eğitimciler, öğrencilerin biyoloji konularında geçen canlılara ilişkin korkuları ve hassasiyetleri dikkate almalı ve korkularını azaltmak için bu canlılarla öğrencilerin etkileşimleri artırılmalıdır. Öğrencilerin hastalık yapıcı etkenlerden nasıl korunabileceği biyoloji derslerinde konu edinilebilir ve tartış1labilir. Öğrencilerin biyoloji derslerinde zorlandığı konular belirlenebilir ve derslerde bu konuların işlenmesinde daha dikkatli davranılabilir. Konuların öğretiminde proje çalışmaları ve sorgulayıcı öğrenme gibi öğrencilerin ilgisini ve tutumlarını geliştirebilecek ve öğrencinin daha aktif rol aldığı öğrenme yöntem ve tekniklerine yer verilebilir. Araştırmacılar, öğrencilerin biyoloji korkusu, sebepleri, etkileyen etmenler ve canlılara yönelik korkuları üzerine daha geniş çalışma grupları ile daha fazla çalışma yapabilirler. Öğrencilerin biyoloji korkusu ile akademik başarı ilişkisine yönelik çalışmalar da gerçekleştirilebilir.

Çalışma, katılımcıların belirlenmesinde kolay ulaşılabilir durum örneklemesi yönteminin kullanılması, katılımcı sayısının 9. ve 10. sınıf öğrencilerinden oluşan $70 \mathrm{kız}$ öğrenci ile gerçekleştirilmesi bakımından sınırlılık içermektedir. Bu sebeple katılımcılar rastlantısal örnekleme yöntemleri gibi farklı örnekleme yöntemleri kullanılarak daha geniş ve her sınıf düzeyinin dahil olduğu çalışmalar gerçekleştirebilirler.

\section{Kaynaklar}

Acarli, D. S., \& Acarli, H. A. (2020). Examination of students' attitudes towards biology and biology course in terms of gender, grade level and pet-keeping. Problems of Education in the 21 st Century, 78(3), 328-341.

Anderson, L. W. (1988). Attitudes and their measurement. Educational research methodology and measurement: An international handbook. J. P. Keeves (Ed.). Oxford: Pergamon.

Arrindell, W. A. (2000). Phobic dimensions: IV. The structure of animal fears. Behaviour Research and Therapy, 38(5), 509-530. Doi: https://doi.org/10.1016/S00057967(99)00097-2.

Ataş, E. (2018). Fen bilimleri öğretmen adaylarının biyoloji kavramına yönelik zihinsel algıları. Anadolu Öğretmen Dergisi, 2(2), 100-113.

Atik, A. D., \& Erkoç, F. (2015). The investigation of 9th grade students' attitudes towards the science and the course of biology in terms of various variables. Adlyaman University Journal of Educational Sciences, 5(2), 211-244. 
Atik, A. D., Tan, Ş., Doğan, Y., \& Erkoç, F. (2018). Lise öğrencilerinin biyolojiye yönelik tutum, öz-yeterlik ve akademik başarıları arasındaki ilişki. Sosyal Bilimler Dergisi, 8(16), 170-187.

Ay-Solmaz, B. (2017). Korkusu olan ve olmayan 3-6 yaş arası çocukların, anne baba tutumlarının ve anne baba kaygısının çocukların korkularına olan etkisinin incelenmesi. (Yayımlanmamış yüksek lisans tezi). İstanbul Arel Üniversitesi Sosyal Bilimler Enstitüsü, İstanbul.

Bahar, M., Johnstone, A. H., \& Hansell M. H. (1999). Revisiting learning diffucilties in biology. Journal of Biological Education, 33(2), 84-86.

Başar, M., \& Doğan, M. C. (2020). Öğrencilerin matematik korkusunun incelenmesi. Turkish Journal of Educational Studies, 7(3), 1-26.

Berberoğlu, G. (2007). Türk bakış açısından PISA araştırma sonuçları. 23. 05.2020 tarihinde http://www.konrad.org.tr/Egitimturk/07girayberberoglu.pdf. adresinden erişildi.

Burkovik, Y., \& Tan, O. (2006). Korkacak ne var! Korkunun psikolojisi. İstanbul: Timaş Yayınları.

Büyüköztürk, S., Kılıç-Çakmak, E., Akgün, Ö., Karadeniz, S., \& Demirel, F. (2018). Eğitimde Bilimsel Araştırma Yöntemleri (25. baskı). Ankara: Pegem Akademi.

Chiappetta, E. L., \& Fillman, D. A. (2007). Analysis of five high school biology textbooks used in the United States for inclusion of the nature of science. International Journal of Science Education, 29(15), 1847-1868.

Chuang, H. F., \& Cheng, Y. J. (2003). A study on attitudes toward biology and learning environment of the seventh grade students. Chinese Journal of Science Education, 11(2), 171-194.

Çepni, S. (2014). Araştırma ve proje çalışmalarına giriş (8. baskı). Ankara: Pegem Akademi Yayınc1lik.

Creswell, J. W. (2003). Research design: qualitative, quantitative, and mixed methods approaches (2nd ed.). Thousand Oaks, CA: Sage.

Davey, G. C. (1994). Self-reported fears to common indigenous animals in an adult UK population: the role of disgust sensitivity. British Journal of Psychology, 85(4), 541-554.

Demirbaş, M., \& Yağbasan, R. (2006). Fen bilgisi öğretiminde bilimsel tutumların işlevsel önemi ve bilimsel tutum ölçeğinin Türkçe'ye uyarlanma çalışması. Uludă̆ Üniversitesi Eğitim Fakültesi Dergisi, 19(2), 271-299.

Dervisoglu, S., Menzel, S, Soran, H., \& Boegeholz, S. (2009). Influence of values, beliefs and problem perception on personal norms for biodiversity protection. Hacettepe University Journal of Education, 37, 50-59.

Dhindsa, H. S., \& Chung, G. (2003). Attitudes and achievement of Bruneian science students. Internalational Journal of Science Education, 25, 907-922.

Durdukoca, S. F., \& Önel, A. (2020). Determining the attitudes and metaphoric perception of prospective science teachers toward biology courses. Asian Journal of Education and Training, 6(2), 136-143.

Ekici, G., \& Hevedanlı, M. (2010). Lise öğrencilerinin biyoloji dersine yönelik tutumlarının farklı değişkenler açısından incelenmesi. Türk Fen Eğitimi Dergisi, 7(4), 97-109. 
Erten, S. (2008). Interests of 5th throuhg 10th grade students toward human biology. Hacettepe Üniversitesi Eğitim Fakültesi Dergisi, 35(35), 135-147.

Etobro, A. B., \& Fabinu, O. E. (2017). Students' perceptions of difficult concepts in Biology in senior secondary schools in Lagos State. Global Journal of Educational Research, 16(2), 139-147.

Fauzi, A., \& Mitalistiani, M. (2018). High school biology topics that perceived difficult by undergraduate students. Didaktika Bıologi: Jurnal Penelitian Pendidikan Biologi, 2(2), 73-84.

Fauzi, A., \& Fariantika, A. (2018). Courses perceived difficult by undergraduate students majoring in biology. Biosfer: Jurnal Pendidikan Biologi, 11(2), 78-89.

Freedman, J. L., Sears, D. O., \& Carlsmith, J. M. (1989). Sosyal psikoloji (Çev. A. Dönmez). İstanbul: Ara Yayınları.

Fraser, H., \& Honeyford, G. (2000). Children, parents and teachers enjoying numeracy: Numeracy hour success through collaboration. London: David Fulton.

Green, G. W. (1999). Çocuğuma matematiği nasıl anlatırım? (Çev. A. Yurdaçalış). İstanbul: Beyaz Yayınları.

Goetz, T., Frenzel, A. C., Pekrun, R., Hall, N. C., \& Lüdtke, O. (2007). Between-and withindomain relations of students' academic emotions. Journal of Educational Psychology, 99(4), 715-733.

Güneş, M. H., \& Güneş, T. (2005). İlköğretim öğrencilerinin biyoloji konularını anlama zorlukları ve nedenleri. Ahi Evran Üniversitesi Kırşehir Ĕ̈itim Fakültesi Dergisi, 6(2), $169-175$

Güneş, M. H., Şener, N., Germi, N. T., \& Can, N. (2013). Fen ve teknoloji dersinde laboratuvar kullanımına yönelik öğretmen ve öğrenci değerlendirmeleri. Dicle Üniversitesi Ziya Gökalp Eğitim Fakültesi Dergisi, 20, 1-11.

Harman, G., \& Şeker, R. (2019). Fen Bilgisi öğretmen adaylarının fizik, kimya ve biyoloji deneylerine yönelik algılarının metaforlar aracılığ ile incelenmesi. Celal Bayar Üniversitesi Sosyal Bilimler Dergisi, 17(1), 153-174.

Harrison A. G., \& Treagust, D. F., (2000). Learning about atoms, molecules, and chemical bonds: A case study of multiple-model use in Grade 11 Chemistry. Science Education, 84(3), 352-381.

Hoffman, B. (2010). I think I can, but I'm afraid to try: The role of self-efficacy beliefs and mathematics anxiety in mathematics problem-solving efficiency. Learning and Individual Differences, 20(3), 276-283.

Huberman, M., \& Miles, M. B. (2002). The qualitative researcher's companion. Thousand Oaks: SAGE Publications Inc.

Hruschka, D. J., Schwartz, D., St. John, D. C., Picone-Decaro, E., Jenkins, R. A., \& Carey, J. W. (2004). Reliability in coding open-ended data: Lessons learned from HIV behavioral research. Field Methods, 16(3), 307-331.

İnceoğlu, M. (2010). Tutum, algl, iletişim. İstanbul: Beykent Üniversitesi Yayınları.

Jameson, M. M. (2010). Math anxiety: Theoretical perspectives on potential influences and outcomes. Anxiety in schools: The causes, consequences, and solutions for academic anxieties (Ed. J. C. Cassady). Newyork: Peter Lang Inc. 
Johnstone, A. H., \& Mahmoud, N. A. (1980). Isolating topics of high perceived difficulty school biology. Journal of Biological Education, 14(2), 163-166.

Köknel, Ö. (2004). Korkular, takıntılar, saplantılar (5. Basım). İstanbul: Altın Kitaplar Yayınevi.

Kubiatko, M. (2012). Kindergarten children's perception of animals focusing on the look and fear of animals. Educational Sciences: Theory and Practice, 12(4), 3181-3186.

Lazarowitz, R., \& Penso, S. (1992). High school students' difficulties in learning biology concepts. Journal of Biological Education, 26(3), 215-223.

Lazarus, R. S. (1991). Emotion and adaptation. New York: Oxford University Press.

MEB (2015). Uluslararası öğrenci değerlendirme programı (PISA) 2015 ulusal raporu. 24.05.2019 tarihinde http://pisa.meb.gov.tr/wp-content/uploads/2014/11/PISA2015_ UlusalRapor.pdf._adresinden erişildi.

Mineka, S., \& Zinbarg, R. (2006). A contemporary learning theory perspective on the etiology of anxiety disorders: It's not what you thought it was. American Psychologist, 61(1), 1026.

Morgan, J. M. (1992). A theoretical basis for evaluating wildlife-related education programs. The American Biology Teacher, 54(3), 153-157.

Morgan, D. (1995). Invisible women: Young women and feminism. Feminist activism in the $1990 s$ (Ed. G. Griffin). London: Taylor and Francis.

Moss, J. (2019). An investigation of seventh grade students' attitudes towards animals in a middle school science classroom in rural Alabama (Unpublished doctoral dissertation). Department of Education Auburn University, Auburn.

Yavuz Mumcu, H. (2020). Ortaokul öğrencilerinin matematik algılarının resmetme yoluyla incelenmesi. Kastamonu Education Journal, 28(1), 371-388. Doi:10.24106/kefdergi.3620.

Mutlu, M. (2006). The relation between the learning styles of the students in Anatolian high schools, Anatolian teachers high schools science high schools and their attitudes towards biology course. International Journal of Environmental and Science Education, 1(2), $148-162$.

Oghii, O. (2015). Anaokulu ve ilkokula giden çocukların cinsiyet, yaş ve kültürel farklllıklarına göre korkuları: Kültürler arası araştırma (Yayımlanmamış yüksek lisans tezi). Orta Doğu Teknik Üniversitesi Eğitim Bilimleri Bölümü, Ankara.

Oğuz, V. (2019). Fear and reasons of children in preschool. Journal of Human Sciences, 16(1), 192-204. Doi:10.14687/jhs.v16i1.5657.

Okereke, I. E., \& Nzewi, U. M. (2020). Fear-inducing stimuli among students during Biology practical activities involving animal specimens. Journal of The Nigerian Academy of Education, 14(2), 177-189.

Ormrod, J. E. (2013). Öğrenme psikoloji (Çev: Ed. M. Baloğlu). Ankara: Nobel Yayınları.

Osborne, J., Simon, S., \& Collins, S. (2003). Attitudes towards science: A review of the literature and its implications. International Journal of Science Education, 25(9), 10491079. 
Özarslan, M. (2019). Üstün zekâlı ve yetenekli olan ve üstün zekâlı ve yetenekli olmayan öğrencilerin biyolojiye ilişkin algılarının karşılaştırılması: Metaforik çalışma. Pamukkale Üniversitesi Ë̆itim Fakültesi Dergisi, 45, 310-334.

Özarslan, M., \& Çetin, G. (2018). Öğrencilerin sağlıklı beslenme hakkındaki düşüncelerinin çizme-yazma tekniği ile belirlenmesi. Inonu University Journal of the Faculty of Education, 19(1), 101-118.

Özbaş, S. (2016). Lise öğrencilerinin biyoloji dersine yönelik tutumları. Electronic Turkish Studies, 11(9), 659-668. Doi: http://dx.doi.org/10.7827/TurkishStudies.

Özel, M., Prokop, P., \& Uşak, M. (2009). Cross-cultural comparison of student attitudes toward snakes. Society \& Animals, 17(3), 224-240.

Öztop, F., \& Toptaş, V. (2017). İlkokul 4. Sınıf öğrencilerinin matematik dersine yönelik korkusu ve altında yatan sebepler. International Journal of Education Technology and Scientific Researches, 2(3), 162-173.

Prokop, P., Fančovičová, J., \& Kubiatko, M. (2009). Vampires are still alive: Slovakian students' attitudes toward bats. Anthrozoös, 22(1), 19-30.

Prokop, P., Kubiatko, M., \& Fančovičová, J. (2008). Slovakian pupils' knowledge of, and attitudes toward, birds. Anthrozoös, 21(3), 221-235.

Prokop, P., Prokop, M., \& Tunnicliffe, S. D. (2007). Is biology boring? Student attitudes toward biology. Journal of Biological Education, 42(1), 36-39.

Prokop, P., \& Tunnicliffe, S. D. (2008). "Disgusting" Animals: Primary school children's attitudes and myths of bats and spiders. Eurasia Journal of Mathematics, Science \& Technology Education, 4(2), 87-97.

Prokop, P., Uşak, M., Erdoğan, M., Fancovicova, J., \& Bahar, M. (2011). Slovakian and Turkish students' fear, disgust and perceived danger of invertebrates. Hacettepe Üniversitesi Eğitim Fakültesi Dergisi, 40(40), 344-352.

Randler, C., Ilg, A., \& Kern, J. (2005). Cognitive and emotional evaluation of an amphibian conservation program for elementary school students. Journal of Environmental Education, 37(1), 43-52.

Robins, L. N., \& Regier, D. A. (1991). Psychiatric disorders in America. New York: The Free Press.

Rodrigues, K. J. (2012). It does matter how we teach math. Journal of Adult Education, 4l(1), 29-33.

Staeck, L. (1995). Perspectives for biological education-challenge for biology instruction at the end of the 20th century. Hacettepe Üniversitesi Eğitim Fakültesi Dergisi, 11(11), 29-35.

Şimşek, H., \& Yıldırım, A. (2011). Sosyal bilimlerde nitel araştırma yöntemleri. Ankara: Seçkin Yayıncılık.

Taş, U. E., Arıcı, Ö., Ozarkan, H. B., \& Özgürlük, B. (2016). Uluslararası ögrenci değerlendirme programı. PISA 2015 ulusal raporu. T.C. Millî Eğitim Bakanlığ Ö̈lçme, Değerlendirme ve Sinav Hizmetleri Genel Müdürlüğü. 24. 05. 2019 tarihinde http://odsgm.meb.gov.tr/test/analizler/docs/PISA/PISA2015_Ulusal_Rapor.pdf. adresinden erişildi.

Tavşancıl, E. (2010). Tutumların ölçülmesi ve SPSS ile veri analizi (4. Baskı). Ankara: Nobel Yayınları. 
Tekbıyık, A., \& Akdeniz, A. R. (2008). İlköğretim fen ve teknoloji dersi öğretim programını kabullenmeye ve uygulamaya yönelik öğretmen görüşleri. Necatibey Eğitim Fakültesi Elektronik Fen ve Matematik Eğitimi Dergisi, 2(2), 23-37.

Tobias, S., \& Weissbrod, C. (1980). Anxiety and mathematics: An update. Harvard Educational Review, 50(1). 63-69. Doi: 10.17763/haer.50.1.xw483257j6035084.

Tomažič, I. (2008). The influence of direct experience on students' attitudes to, and knowledge about amphibians. Acta Biologica Slovenica, 51(1), 39-49.

Uyanık, G. K., Güler, N., Teker, G. T., \& Demir, S. (2019). The analysis of elementary science education course activities through Many-Facet Rasch Model Kastamonu Education Journal 27(1), 139-150.

Vekli G., Ş (2018). Türkiye'de biyoloji öğretiminde yaşanılan sorunlar ve çözüm önerileri:Akademisyen perspektifi. Akdeniz Eğitim Araştırmaları Dergisi, 12(26), 311329.

Wai, H. O., \& Khine, S. S. (2020). An investigation into the difficulties of students in learning Biology. J. Myanmar Acadademic Arts Sci, 18(9), 183-197.

White, R., \& Gunstone, R. (1998). Probing understanding. USA: The Falmer Press.

Whyte, J., \& Anthony, G. (2012). Maths anxiety: The fear factor in the mathematics classroom. New Zealand Journal of Teachers' Work, 9(1), 6-15.

Yapıcı, İ. (2015). Lise öğrencilerinin biyoloji kavramına ilişkin metaforik algıları. Elektronik Sosyal Bilimler Dergisi, 14(55), 139-147.

Yeşilyurt, S., \& Gül, Ş. (2008). Ortaöğretimde daha etkili bir biyoloji öğretimi için öğretmen ve öğrenci beklentileri. Kastamonu Ĕgitim Dergisi, 16(1), 145-162.

Yılmaz M., Çimen, O., Karakaya, F., \& Üçüncü, G. (2018). Okul öncesi öğretmen adaylarının insan anatomisi ve fizyolojisi dersine yönelik sınav kaygılarına neden olan durumlar ve kayg1 durumunu azaltan etkenler. Anadolu Öğretmen Dergisi, 2(1), 1-18.

\section{EXTENDED ABSTRACT}

\section{Introduction}

It was determined that the students of our country did not have the desired success in international or national examinations in the fields of science and mathematics. (Uyanık et al. 2019). Therefore, the reasons for students' failure in science and mathematics are seen as important by researchers. When the literature is examined, there are the fears of students about the science or course among the reasons of their failure (Rodrigues, 2012). Today, however, researchers have mostly focused on the fear of mathematics (Öztop \& Toptaş, 2017; Whyte \& Anthony, 2012). It is thought that researchers do not focus on especially biology fear in the field of science. For an effective biology teaching, students' fear of biology, the motives behind this fear, and their attitudes towards biology should be determined. Prevention of fear and negative attitudes in biology courses which are especially compulsory in $9^{\text {th }}$ and $10^{\text {th }}$ grade of secondary education is important for the students' subsequent education levels. The result of these studies can contribute to the preparation of biology course activities by educators which will help students to develop positive feelings towards biology course. 


\section{Method}

Descriptive research approach was adopted in the study. The data were obtained by diversification method, in which qualitative and quantitative research methods are applied simultaneously (Büyüköztürk et al., 2018). The study was conducted at the end of 2015-2016 academic year, spring semester. The participants consisted of totally 70 female students attending in $9^{\text {th }}$ and $10^{\text {th }}$ grades of Vocational and Technical Anatolian High School in a district center of Marmara region. These classes were preferred because the biology classes are offered at this level. The working group was determined by the easily accessible case sampling method (Büyüköztürk et al., 2018). The data were obtained by applying the Attitude Scale towards Biology Science and Course and by the questionnaire of Biology Fear. In the study, descriptive statistical analysis was used for the analysis of quantitative data and descriptive and content analysis technique was used for the analysis of qualitative data.

\section{Results}

According to the research findings, it was determined that the majority of students have a fear of biology. In students' thoughts and drawings about fear of biology; they were often found to have fears of failure, inability to understand subjects, and confusing what they learned. Concerning the reasons for their fears, students stated that they could not understand the subjects, they had difficulty in solving the questions in the exams and the subjects were complicated and difficult. In addition, both in the students' thoughts and drawings, students' fears were determined about living things (insects, bacteria, intestinal worms, etc.), human body, genetics, bones, skin, cells and hereditary diseases which are the topics of biology. It was determined that students' general attitude scores were low, they did not like biology and its subjects and they got bored.

\section{Discussion and Conclusion}

Research results showed that students had fears of having difficulty, failing to understand the subjects and being unsuccessful in biology courses. These results were similar to those of the previous research studies in the literature, which demonstrated that students believed biology course was one of the most difficult courses and they had difficulty in understanding (Chuang \& Cheng, 2003; Güneş \& Güneş, 2005; Staeck, 1995).

Research results show that insects, viruses, bacteria, intestinal worms, snakes, etc. which are in the content of the students' biology topics create a fear of biology in students. These results have similarities with those in the literature in which the students developed fears and negative attitudes towards living things (Ay Solmaz, 2017; Kubiatko, 2012; Oğuz, 2019; Prokop et al., 2008; Prokop et al., 2009). This situation stems from the students' desire to be healthy and to be protected from diseases and the thought of being affected negatively by the damages of the living organisms (Erten, 2008; Prokop et al., 2011).

In the research results, it was determined that the students experienced fears about genetics, reproduction, cell division and human anatomy. These results were thought to emerge from issues that students had difficulty in learning in the biology classes. Because the results of this research are similar to the results of the literature in which students find it difficult to understand genetics, respiration and nervous system. (Bahar et al., 1999; Chiappetta \& Fillman, 1998; Fauzi \& Mitalistiani, 2018; Güneş \& Güneş, 2005).

According to the results of the research, it was determined that sub-level attitude scores of students' general attitude towards biology science and course, interest towards biology science, enjoyment of biology course and anxiety about biology course were low. In addition, both in 
Öğrencilerin Biyoloji Korkusu ve Biyolojiye Yönelik Tutumları

students' thoughts and drawings, it was found that the students did not like biology and subjects and got bored. These results coincided with the research results of Gül and Yeşilyurt (2010) in which it was determined that students considered biology as a waste of time, were prejudiced against biology and they disliked this course. However, in the literature, there were studies showing that students' attitudes towards biology course were positive (Atik et al., 2018; Prokop, et al., 2007).

For a better understanding of biology, educators can relate what have been learnt with the daily life in teaching biology and concentrate on experimental practices. Educators should take into account students' fears and sensitivities about biological life and increase students' interaction with them in order to reduce their fears. Since the sensitivity of female students to diseasecausing factors is known, more emphasis can be placed on how individuals can be protected from disease-causing factors in biology classes.

\section{Etik Kurul İzin}

Yapılan bu çalışmada bilimsel, etik ve alıntı kurallarına uyulduğu, toplanan veriler üzerinde herhangi bir tahrifatın yapılmadığı, karşılaşılacak tüm etik ihlallerde "Asya Öğretim Dergisi ve Editörünün" hiçbir sorumluluğunun olmadığı, tüm sorumluluğun Sorumlu Yazara ait olduğu ve bu çalışmanın herhangi başka bir akademik yayın ortamına değerlendirme için gönderilmemiş olduğu sorumlu yazar tarafından taahhüt edilmiştir. Bu çalışmanın verileri 2020 yılından önce toplandığı için etik kurul onayı alınmamıştır. 